\title{
The First Globalized Economy: Privateers, Joint-Stock Companies, Commerce and the Rise of the United Provinces
}

\author{
Emmanouil M. L. Economou (Corresponding author) \\ Department of Economics, University of Thessaly \\ PO Box 38333, Volos, Korai 43 Street, Greece \\ Tel: 306978811233 E-mail: lazaros19811981@gmail.com
}

\author{
Nicholas C. Kyriazis \\ Department of Economics, University of Thessaly \\ PO Box 38333, Volos, Korai 43 Street, Greece \\ E-mail: nkyr@uth.gr
}

Received: July 10, 2015 Accepted: July 20, 2015 Published: September 29, 2015

doi:10.5296/ijssr.v3i2.7982 URL: http://dx.doi.org/10.5296/ijssr.v3i2.7982

\begin{abstract}
In this paper we analyse the reasons of the rise of the United Provinces (UP) or alternatively, the Dutch Republic, as the first modern European economy since 1500 and afterwards. We focus on some major institutional innovations that were developed in the UP, such as joint-stock companies, privateering, commercial and banking activities, and the first ever recorded stock market. We argue that all these institutions flourished under a political system which was functioning through a series of many democratic elements. Lastly, we argue that the paradigm and the institutions of the UP could be seen as an inspiration for the development and the further political and economic integration of the European Union.
\end{abstract}

Keywords: Institutions, partnership companies, privateers, $16^{\text {th }}-17^{\text {th }}$ century United Provinces 


\section{Introduction}

In the middle of the $16^{\text {th }}$ century what is now the Netherlands was part of the Spanish Empire, through a series of dynastic marriages following the fall of Burgundy, to which it had belonged previously. The United Provinces were a relatively poor region, without any notable naval strength and tradition. During the Middle Ages the larger North Sea ports in the area of today's Belgium and the Netherlands, were Brügge, Ghent and Antwerp. During the period when the United Provinces were a part of the Spanish Habsburg Empire, the value of Amsterdam's exports was only 4\% of the total exports of those ports, whereas Antwerp's exports were as high as $80 \%$.

The UP was surrounded by hostile territories. Today's Belgium and Luxembourg territories in the southwest were controlled by hostile forces, the Spanish Empire, while in the southeast borders the German states were under another branch of the Hapsburgs, emperors of the "Holy Roman Empire of the German Nation".

However, during the $17^{\text {th }}$ century the UP became the greatest naval empire, with great economic strength, capable of defeating even the strong English navy in 1666 during the second (out of the three) Anglo-Dutch war. During the $16^{\text {th }}$ century a series of economic, social and religious issues led the Dutch Protestants of Holland to revolt against the authority of the Catholic Habsburg Spanish Empire in 1568. War lasted for 80 years and ended with the Westphalia Treaty of 1648. But essentially, the UP were independent since the end of the $16^{\text {th }}$ century.

In the next section we analyse the UP's political institutions to show their democratic nature in general. Then, in Section 3 we analyse two basic aspects that accompanied the Dutch "turn to the sea" strategy concerning the economy, the privateer activity and the joint-stock companies. In Section 4 we analyse in detail the case of the Dutch East Indian Company (VOC) while in Section 5 we analyse in more detail the Dutch "Sea Beggars". In Section 6 we integrate the analysis by taking into account other aspects of the rise of the Dutch economy such as the introduction of banking services and the establishment of the stock market. We conclude by offering some comments and suggestions as to the functioning of our modern economies and the European Union.

\section{The Political Organisation of the UP: The Historical Background in Brief ${ }^{1}$}

The UP took a specific political and institutional shape through the Utrecht Treaty of 1579 which created an alliance of provinces against the common enemy, the Spanish Empire. Gradually the UP evolved into a political unit that proved stable and capable of creating the circumstances for economic development that would lead to the emergence of the first early modern European economy and financial revolution (de Vries and van der Woulde, 1997).

\footnotetext{
${ }^{1}$ For a detailed analysis of the UP political and economic system, see de Vries and van der Woude (1997), t' Hart (1996), Halkos and Kyriazis (2005), Kyriazis (2006, 2012), Davids and t' Hart (2012) and the additional references provided there. For the Dutch War of Independence, see Parker (1977).
} 


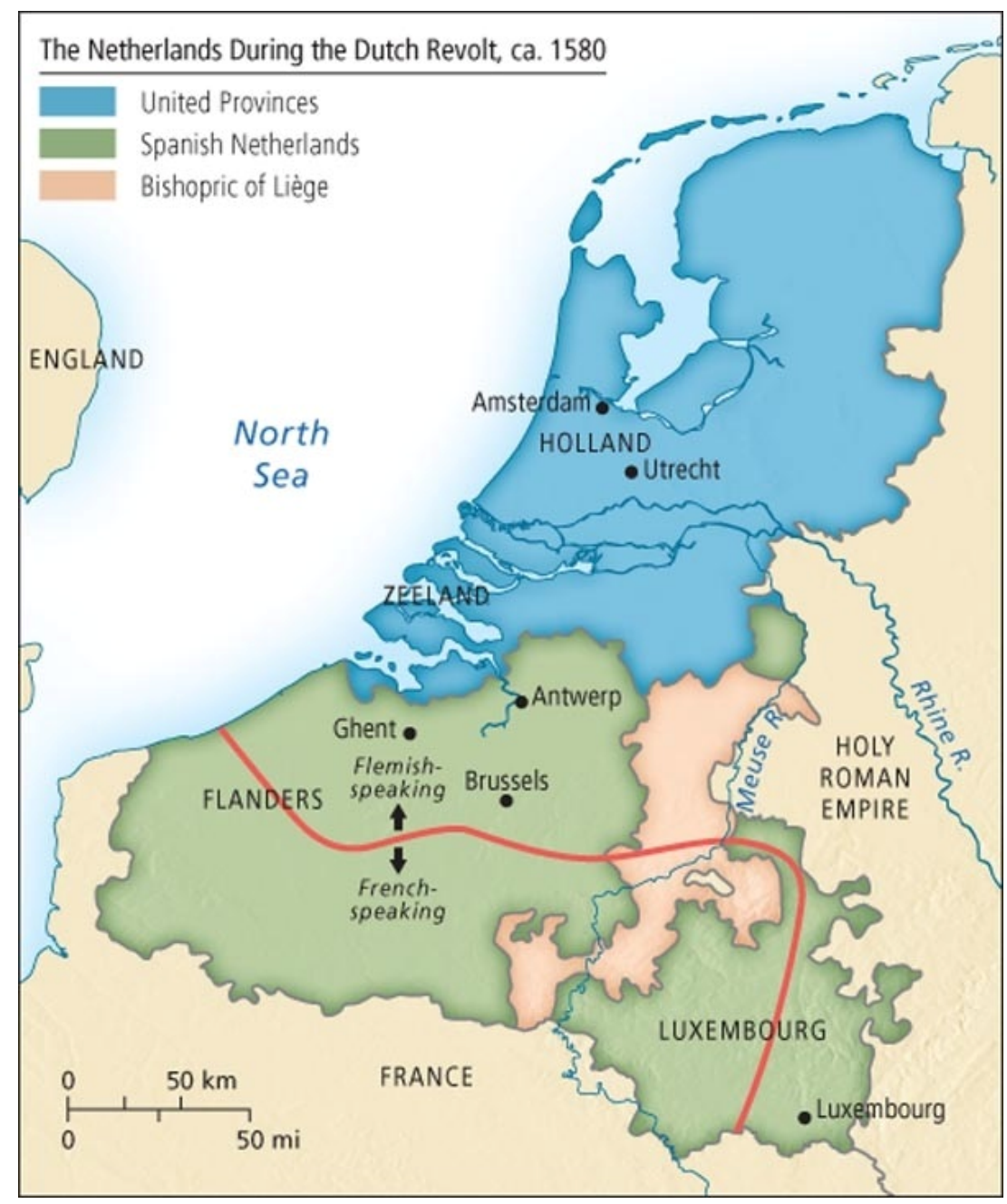

Figure 1. United Provinces territory (blue colour) during the revolt era

Source: http://www.miraed.net/parallelhistory/event_display_get.php?fname=

Dutch\%20Revolt

The main institutional body was the Estates General which met every day, even on Sundays. To these meetings every province could send a representative, who could vote on a variety of issues under discussion, such as foreign relations, alliances, war or peace strategy, federal budget, federal taxation and tariffs. Thus, the Estates General could be seen as a version of a Parliament comprised of members that were elected in a number of cities in each of the seven provinces. Holland, which was the most affluent province, was burdened with $58 \%$ of the total federal tax (Amsterdam being responsible for $27 \%$ of the $58 \%$ ), while the least affluent province, Overijssel, paid only $4 \%$ of the federal tax. We are referring to "federal" mechanisms since the UP evolved into a quasi-federal entity as we will further analyse.

The second federal body was the "State's Council" comprised of 25 elected members by the Provinces. This council had a president called "stadtholder" (standthouder in Dutch) who 
could be considered as the "President" of the UP. This position was hereditary and was open only to members of the Orange-Nassau House. However, there was a period, during 1652-1672, when this position was vacant and authority was exercised in practise by the de Witt brothers. Every province was governed by a stadtholder, but in practise there was the same stadtholder for each of the seven Provinces, the Prince of Orange-Nassau. The council and the stadtholder were entrusted with military, financial and other business, e.g., an executive power. The fleet was under the control of the State's General and the admiral-general, but the daily conduct of naval affairs was in the hands of the five Admiralty Colleges.

Thus the stadtholder seems to have been a de facto head of state, if we interpret his position in modern practical terms. He had the authority to appoint several high-ranking magistrates in Dutch cities, to pardon people or reduce their penalties. However, the strength of his political position varied, and basically it was determined by his personal administrative capabilities. Capable stadtholders were, for example, William I the Silent, who ruled the UP between 1544 and 1584 and William III, who was a stadtholder during 1672-1702 and also King of England and Ireland from 1689 to $1702 .^{2}$

Thus the stadtholder seems to have been a de facto head of state, if we interpret his position in modern practical terms. He had the authority to appoint several high-ranking magistrates in Dutch cities, to pardon people or reduce their penalties. However, the strength of his political position varied, and basically it was determined by his personal administrative capabilities. Capable stadtholders were, for example, William I the Silent, who ruled the UP between 1544 and 1584 and William III, who was a stadtholder during 1672-1702 and also King of England and Ireland from 1689 to $1702 .^{3}$

The Seven Provinces were comprised of 58 cities and each city had the right to send representatives to the federal Estates General. For example, the province of Holland could send 18 representatives that had been elected by their cities as well as a representative from the aristocracy. Zeeland provided six representatives from its cities and one aristocrat. At the city level, the administration was exercised by the mayors of the city who could number two, three or even four, assisted in their duties by seven or more advisors (aldermen). Those advisors were elected by a body called vroedschap, the town council. The mayors and the rest of the town council members, the vroedschappen were engaged in the daily management of the city. In most cities, the mayors were elected for a term of four years. When a vroedschap member died the others decided democratically his replacement by shouting. ${ }^{4}$

Ordinary citizens did not have the right to vote. However, they had indirect substantial

\footnotetext{
${ }^{2}$ William married Mary, the daughter of the King of England James II Stuart. William overthrew James II with the support of substantial English circles and the capable Dutch navy which landed troops in England in 1688. Then, William offered many privileges to the English Parliament and converted the political system from an absolute one into the first modern constitutional monarchy (North and Weingast, 1989).

3 William married Mary, the daughter of the King of England James II Stuart. William overthrew James II with the support of substantial English circles and the capable Dutch navy which landed troops in England in 1688. Then, William offered many privileges to the English Parliament and converted the political system from an absolute one into the first modern constitutional monarchy (North and Weingast, 1989).

${ }^{4}$ Reminiscent of the procedure taking place in the ancient Spartan assembly of citizens, called Apella.
} 


\section{Macrothink}

International Journal of Social Science Research

ISSN 2327-5510

2015, Vol. 3, No. 2

political power since they formed the city's militia and the local guard for the safety of its city. Thus, during the Dutch revolt no municipal body could ignore the will of the militia, the will of the simple people.

However, during the $17^{\text {th }}$ century the political system in the UP became more oligarchic. The number of town council members was reduced and, in practice, administrative authority was being undertaken by wealthy members and members of the aristocracy, the so called rejenten. For example, in Amsterdam the administration of the city was exercised by a group of four mayors who were not elected by the city's citizens or the stadtholder. Instead, they were elected internally, by previous mayors and a few citizens from the vroedschappen. Thus, any external check on the actions of the rejenten was very limited. We don't know, however, why the initial democratic practise of local governance was replaced by a more oligarchic political structure.

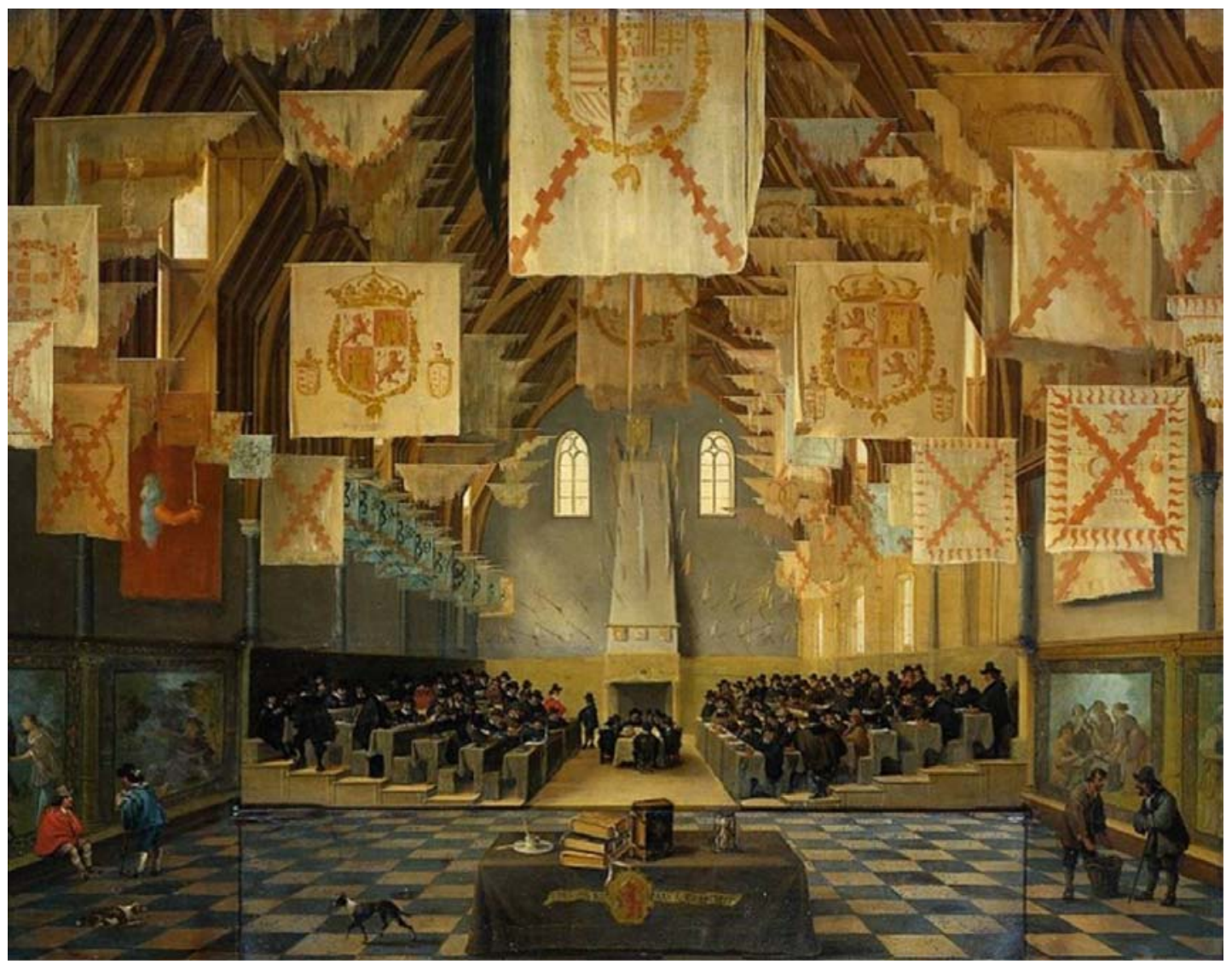

Figure 2. The Estates General meeting of 1651

Source:

http://en.wikipedia.org/wiki/Politics_and_government_of_the_Netherlands_(1581\%E2\%80\% 931795)

Thus the United Provinces could be characterised as "a democratic head (the elected Estates 
General, where each province had a veto right due to the unanimity rule) in an oligarchic body" (the non-elected city-states local administrations, the regents or regenten). As a final comment regarding the political organization of the UP, it could be argued that the UP had established a political system with many checks and balances, especially between various federal levels, (cities and provinces) which proved to be "durable" and efficient throughout time, and were the foundation for a prosperous economy as we will analyse in the next section. The UP managed to create one of the first "fiscal-military states" in practice, by achieving a community of interest, which mobilized the necessary resources for maintaining armies on land and their mighty fleets of the 16 to the $17^{\text {th }}$ centuries.

\section{The Dutch Revolt and the "Turn to the Sea Strategy"}

As has already been mentioned, when the Dutch revolt started in 1568, the Dutch faced a serious external threat and shock, the Spanish invasion. The Spanish Empire was a formidable enemy, probably, the most powerful military power in Europe in that era.

It had gradually established the world's biggest overseas and maritime empire, including the Benelux countries, many parts of today's Central and Latin America (by subduing the Indian Aztec, Inca and Maya empires as well as islands such as Cuba and Puerto Rico) parts of Chile and areas such as today's California, Florida, and today's Philippines.

Thus, if we interpret the situation through Toynbeean spectacles, the Dutch were "challenged" by the Spanish and would either collapse or "respond" effectively. ${ }^{5}$ Historical facts proved that the second possibility was, in fact the case. The Dutch adopted a "turn to the sea strategy" in order to face the Spanish at sea as their capabilities on land were far inferior to those of the Spanish, which were based on the famous tercio regiments. ${ }^{6}$ How did all this happen?

We argue that a major reason has to do with the emergence of the Dutch privateer activities related to warfare and in accordance to this, with the emergence of the first joint stock companies. The Dutch, being encircled on land by Spanish territories, had only one way open to the rest of the world, the sea. They used it to expand commercially by the end of the century making their first attempt to capture the spice trade, which they succeeded in achieving during the next century. Parallel to this, they attacked the most vulnerable points of the Spanish Empire, maritime commerce with their colonies.

During the same period, the Dutch revolt had just started and there were no, as yet, dedicated Dutch warships. On the other hand, the distinction between dedicated warships and armed merchantmen had just started to emerge. Most navies, the Spanish-Portuguese included (which

\footnotetext{
${ }^{5}$ In the 12 volumes of his The Study of History, Toynbee studied 23 different civilizations. He concluded that cultures decline not by external threats but actually, through internal inefficiencies. See Toynbee (1946).

${ }^{6}$ It appears that history repeats itself over time. The first ever recorded case where a "turn to the sea" strategy was implemented in order to face a superior enemy on land, the Persian Empire, was that of the Athenian democracy (510-322 BCE). This Athenian "turn to the sea" strategy led also to a major transformation of the Athenian economy, by making it more extrovert and in some cases, using many institutional mechanisms that could be characterised "modern". See, on this issue, Kyriazis and Zouboulakis (2004). The same happened with England after 1588 when the Englishmen defeated the famous Spanish Armada. On this issue see (Rodger, 1997, 2004).
} 
also comprised some dedicated warships) made up their numbers by using merchantmen. Almost all merchantmen were armed, and by being up-gunned (with the addition of more guns) and up-crewed (with the addition of more crew members to serve the guns and in the Spanish navy with soldiers to serve as boarders) the merchantmen became relatively efficient men of war. $^{7}$

Thus, the Dutch could solve relatively easily the first part of the challenge, the availability of ships. The solution to the second part was less obvious: Who would organise and finance the war operations against the Spanish and how was this to be achieved? In the UP, where the revolt had just started, there was, as yet, not even a rudimentary central federal authority to do it. Market solutions were found: the use of privateers-corsairs for a war, firstly, for a private and secondly, for a public way of making profit (Kyriazis and Metaxas, 2011).

During the $16^{\text {th }}$ century, merchants in the UP and England began to develop a new form of organisation, joint-stock companies, which in the UP were called partenrederij (partnerships) for maritime trade. Similar forms of organisations were created already in prototype forms in ancient and medieval maritime societies, such as Athens, Rhodes, Rome, Venice, Pisa and Genoa leading us to assert that similar problems lead to similar solutions over the ages. The Italian experience may have influenced England and the UP, as Venetian banking influenced banking in the UP, the Bank of Amsterdam being modelled, for example, on the Venetian Banca de la Piazza di Rialto or the Banca di St. Giorgio in Genoa Schmitthoff (1939) and Ferguson (2009). Hildreth (1837, repr. 1971) argued that similar mechanisms had also been developed in Barcelona and some free independent German states of that era.

Introducing a joint stock company meant that a series of would-be investors wished to participate, with a specific sum of money, in the launch of a new journey to Asia or the Americas, for taking part in commercial action. Each shareholder was responsible for his share only. If the journey proved to have been prosperous, profits were shared fairly between the shareholders, according to the percentage of each shareholder's contribution. In case of a loss, the shareholder's damage was limited only to the financial contribution he had made in forming the company (Robins, 2012, p. 24). Then, the joint stock company was dissolved, but it could be re-shaped as a new, similar, company for a new activity. Kyriazis and Metaxas (2011, p. 365) add to this point that once the feasibility of the venture had been proven, as well as its profitability, decision-makers had an incentive to repeat it. And so, in order to avoid incurring transaction costs related to the establishment and dissolving of the company for each voyage, it is reasonable to expect that the company's life horizon would be extended for longer durations. And this is what actually happened.

The Dutch had developed innovative vessels such as the fluit, a type of commercial ship with relatively slow speed and very light armament but with a long flat keel which permitted its easy entrance in shallow waters, rivers or channels. This kind of ship was a great success and gave a

\footnotetext{
7 The Dutch were so successful against the Spanish with this practice that they discovered quite late and to their detriment the necessity of dedicated warships. This happened after their defeat during the first Anglo-Dutch War of 1652-1654 by English dedicated warships, which forced them to build their own (see Tincey 1988; Rodger 2004 and Davids and t' Hart 2012).
} 
huge boost to the Dutch naval industry. Dutch captains were capable of offering competitive fares to the merchants. Thus during the second half of the $17^{\text {th }}$ century the UP had managed to control three quarters of the entire European commercial fleet in tonnage.

\section{The Rise and Functioning of the Dutch East Indian Company (VOC)}

On 2 April 1595 three ships fitted out by a Dutch partenrederij' sailed from Texel and returned in August 1597, with 87 survivors out of the original crew of 240. The financial results are not known precisely, but it seems that the cargo that was brought back just covered the expenses.

However, more important is the fact that the possibility of establishing an efficient system of trade roots with Asia, new companies were established in Amsterdam, Middellurg, Veere and Rotterdam. 65 ships left the Netherlands for Asia between 1595 and 1602, of which 50 returned, compared to only 46 Portuguese ships between 1591 and 1601 . The trade route was thus established (Zandvliet, 2002, pp. 155, 223, 242; Gaastra, 2003).

It seems to us that the emergence of the international trade was actually a procedure "by trial and error". When the voyages were successful, new knowledge was gained by sailors and gradually a new naval culture and tradition were shaped. The most characteristic case of the Dutch overseas trade was the East India Company (VOC - Verenigde Oost-indische Compagnie) which is often considered by many as the first true multinational corporation.

It was established in 1602 for the purpose of taking part in the trade with Asia and more specifically, for developing trade links for prized commodities such as pepper, clove, nutmeg and cinnamon. At the time, spices were the only means of conserving meat (apart from smoking and salting) imparting to it a flavourful taste. Furthermore, certain spices, such as nutmeg, were thought to be an important medicine.

The VOC had a monopoly of trade with Asia for 20 years, while a first joint-stock (or Kapitaal reKening) would be terminated after 10 years. However, in 1610 the directors of the VOC (the 'Heeren XVII') decided that this would damage the company's potential and with the support of the Estates General VOC became permanent. On 20 March they approved the charter for the Dutch East India Company, the VOC (Steensgaard, 1982; den Heijer, 2002; Gelderblom \& Jonker, 2004). This decision should be considered as a part of a rational behavior and strategy. Table 1 below describes in steps the procedure of the rise and the emergence of the joint stock companies.

When the Dutch first travelled to Asia, all their ships made the long and dangerous voyage from Europe and back. However, this practice was soon replaced. The Dutch captured Jakarta on Java in 1619, renamed it Batavia, and made it the hub of their Asian trade. Small ships were dispatched to trading ports all over Asia and the cargo they brought to the central storehouse was conveyed to Europe by large return-ships. A large part of today's Sri Lanka was occupied. The strategic position of Malacca was taken from the Portuguese in 1641. It didn't take more than 50 years for VOC's expansionism to replace most other local trading networks with their own series of fortified trading posts. VOC had become almost a state in itself with its own ships (military and merchant) and armies, the right to build fortifications 
and to negotiate treaties with local powers. In 1652, Cape Town, at the southern tip of Africa, was founded as a strategic point-link between their Eurasian roots.

VOC essentially achieved a monopoly in the nutmeg and cinnamon trade for about a century and gained substantial profits from its exploitation. Most of it came from the "Spice Islands" in the Banda archipelago in the Dutch East Indies. By 1750, VOC employed around 25,000 people and was doing business in 10 Asian countries. However, signs of decline due to corruption and mismanagement and the invasion of Napoleon of the UP, which created the short-lived Batavian Republic, led to the creation of a new constitution or 'Staatsregeling', determining that the VOC should be nationalised.

The company faced bankruptcy in 1799 and its holdings were transferred to the Dutch Crown. Finally it was abolished on 1 January 1800.

Table 1. The steps towards the creation of the joint - stock companies

\begin{tabular}{ccccc}
\hline Step 1 & Step 2 & Step 3 & Step 4 & Step 5 \\
\hline $\begin{array}{c}\text { Partnerships are } \\
\text { established }\end{array}$ & $\begin{array}{c}\text { Partnerships are } \\
\text { becoming } \\
\text { permanent }\end{array}$ & $\begin{array}{c}\text { Partnerships } \\
\text { merge and } \\
\text { become great } \\
\text { joint-stock } \\
\text { companies }\end{array}$ & $\begin{array}{c}\text { VOC is } \\
\text { established in } \\
1602\end{array}$ & $\begin{array}{c}\text { Dutch stock } \\
\text { exchange is } \\
\text { established in } \\
1602\end{array}$ \\
\hline
\end{tabular}

\section{The Dutch “Sea Beggars” and Their Privateering Operations}

In the early days of the Dutch Revolt, warfare was dominated by the actions of a group of unruly privateers, contemptuously called "beggars" by the Spanish, a name which they proudly took over as "Watergeuzen" (Sea Beggars). Indeed the Sea Beggars liberated the first Netherlands territory from the Spanish, capturing the port of Brill in 1572 in a surprise attack. This was followed rapidly by the capture of a number of other ports, Flushing and Veere (in Zeeland), Enkhuizen (in North Holland) and later of major cities like Amsterdam. Thus, the UP acquired the necessary ports for the expansion of their trade and which served also as privateering bases (Parker, 1977; Israel, 1995).

During the first two decades of the revolt, the port-cities authorities were somewhat reluctant to grant corsairs licences, because some privateers attacked and plundered neutral ships, thus endangering the diplomatic efforts of the Estates General that worked for the recognition of Dutch independence by other states. But in 1598 King Philip of Spain issued an official embargo against the Dutch, forcing the States General to react: All goods and possessions of Spain were legitimate prizes of privateers. In order to limit "outlaw behaviour" by privateers, the States General demanded caution money of 6.000 guilders, later raised to 20.000 , which was forfeited in case of misbehaviour of the captain, e.g., if he attacked neutral ships (van Loo 
1998).

Showing remarkable flexibility in assessing the institutional advantages and disadvantages offered by each location, many Dutch privateers, in a very early case of investment cross border mobility, turned their backs on Holland after 1604, when the States General raised the bail and made conditions for obtaining privateer licences more difficult. Some became pirates, but more often, merchants, joint-stock companies (mainly in Zeeland) financing and contracting French captains (some from Dunkirk) like the famous Nicholas Jarry and Pierre le Turcq. Amsterdam merchants soon followed the example of the Zeeland merchants, financing Dunkirk privateers. Well-to-do merchants from Middleburg (in Zeeland) engaged in the privateering business right up to the end of the $18^{\text {th }}$ century. Another Zeeland port Flushing (Vlissingen) grew into one of the most feared privateering ports of the time (Davids and t' Hart 2012).

We have within the various cities of the early UP an early manifestation of intercity competition that led in the course of time to some maritime specialisation: Amsterdam developed into the most important trading and entrepôt city and thus was less interested over time in privateering business. Some Zeeland ports, like Flushing and Middleburg, which were economically hit by the downfall of neighbouring Antwerp (due, in large part, to a Dutch sea blockade) specialised in the alternative maritime business form of privateering. But even Amsterdam invested heavily in privateering in an indirect form through the prototype joint-stock companies, the Dutch East India Company established in 1602 and the Dutch West India Company (WIC). Amsterdam financial interests were predominant in both (De Vries \& Van der Woude 1997).

The VOC played an important role by undertaking large-scale privateering activities against Spanish and Portuguese ships and colonies in Asia (Gaastra, 2003). The WIC was even more successful in its privateering expeditions, its biggest success coming in 1628, when a company fleet commanded by Piet Heyn managed to capture one Spanish "plata" (silver) fleet off Matanzas in Cuba. It was the only time in history that an entire Spanish treasure fleet was captured. This not only financed the WIC's first successful conquests in Brazil ${ }^{8}$, but also destroyed in one blow about a third of the ships employed in Seville's (Spain's main port in its trade with the New World) Atlantic trade. Between 1623 and 1626 the WIC took or destroyed 547 ships worth about 5,5 mio guilders (Cooper 1970 226-238). This sum was greater than the WIC's total, own capital. The WIC capital was 7 mio guilders, and the value of the silver captured in 1628 was more than 10 mio guilders (Goldsmith, 1983, pp. 214, 305).

Within the Dutch-Spanish conflict, the Dutch were also fighting against the Portuguese, since Portugal had been incorporated since 1580 into the Spanish empire, and remained a part of it till 1640. For example, the Portuguese squadron of the Spanish Armada of 1588 was one of the best, comprised of 12 galleons with 387 guns and 3649 crew (Konstam, 2001a). Portuguese

\footnotetext{
${ }^{8}$ During the 1650s and after Portugal's independence from Spain, the UP and Portugal fought for Brazil and in the end the Portuguese prevailed. Dutch failure in this case was an example of overextension, since they were fighting the English during the same period in the first Anglo-Dutch war, and also the Portuguese in the Indian Ocean.
} 
ships and colonies suffered substantially from Dutch attacks, both in American waters (outside Brazil), Africa (outside Angola) and Asia. In particular, the Dutch thought that these Portuguese colonies were weak links in the Spanish-Portuguese Empire and, by using sea power, they extended their operations ashore, attacking Portuguese strongholds.

In 1624-1625 they took and then lost Bahia, in 1630 they began the conquest of Permambuco (in the northeast region of Brazil) which was completed by John Maurice in 1637, in 1638 they captured Elcina in Guinea (Africa) and started the conquest of coastal Ceylon. In 1640 they defeated a Portuguese armada off Pernambuco and in 1641 they captured Malacca (in southeastern Asia, today's Malacca Straits), the Mercahao and Luanda.

They concluded a Ten Year Trace with the Portuguese in June 1641. Hostilities resumed nevertheless in 1644-1645 with a rebellion against the Dutch in northeastern Brazil, while the Portuguese recaptured Luanda and Benguela in 1648. By 1654 the Portuguese had expelled the Dutch from Brazil. On the other hand, the Dutch completed wresting Coastal Ceylon and Malabar from the Portuguese during 1654-1658. Peace was signed with the now independent (since 1640) Portugal, which left the Dutch dominant in the Indian Ocean and Asia where the Portuguese retained only a few bases, such as Goa in the Indian peninsula and Macao in the Chinese coast (Boxer, 1965).

To be more precise, privateering, but also long range voyages to the spice islands (the Banda archipelago) were in the beginning uncertain but the expected profits were very high (Kyriazis $\&$ Metaxas, 2011). Thus, privateering and the spice voyages (Drake's in 1577 and the first Dutch expedition to the Banda's in 1596) were undertaken and were successful. Thus, after each subsequent expedition, uncertainty was gradually and increasingly, transformed into risk, e.g. probabilities of success or failure could now be more readily calculated and thus also, rates of return on investment. This corresponds to increased knowledge from "learning by voyaging", which reduces information cost, an important element of total transaction cost. Another element is the reduction of transaction cost due to learning by working smoothly together during long voyages and battle, which is exactly how cooperation and coordination operate. ${ }^{9}$

Here, we underline the role of the initiator(s) e.g., those who first undertake the voyage and bear the risk as, for example, Drake or the first Dutch "partenrederij" of 1596. The outcome of the initiator's enterprise gives, in modern language, a signal to the rest of the merchant-naval community. If successful, the signal is positive, and this serves as a diffusion mechanism of knowledge. Signals are information transaction cost reducing mechanisms. At the same time, signals serve as diffusion mechanisms of values, such as trust, which again reduce transaction costs. The fact that privateering both in England and the UP started as individual enterprises of single, or at the most, few ships, but very soon developed into entire fleets and financially much larger enterprises, is an indication that norms such as trust, were becoming more and more community norms and that transaction costs were indeed reduced. ${ }^{10}$

\footnotetext{
9 Erikson (2014) deals explicitly with cooperation and coordination in the EIC.

${ }^{10}$ We owe the development of this argument to penetrating comments by Professor H. Hillmann in a personal communication.
} 


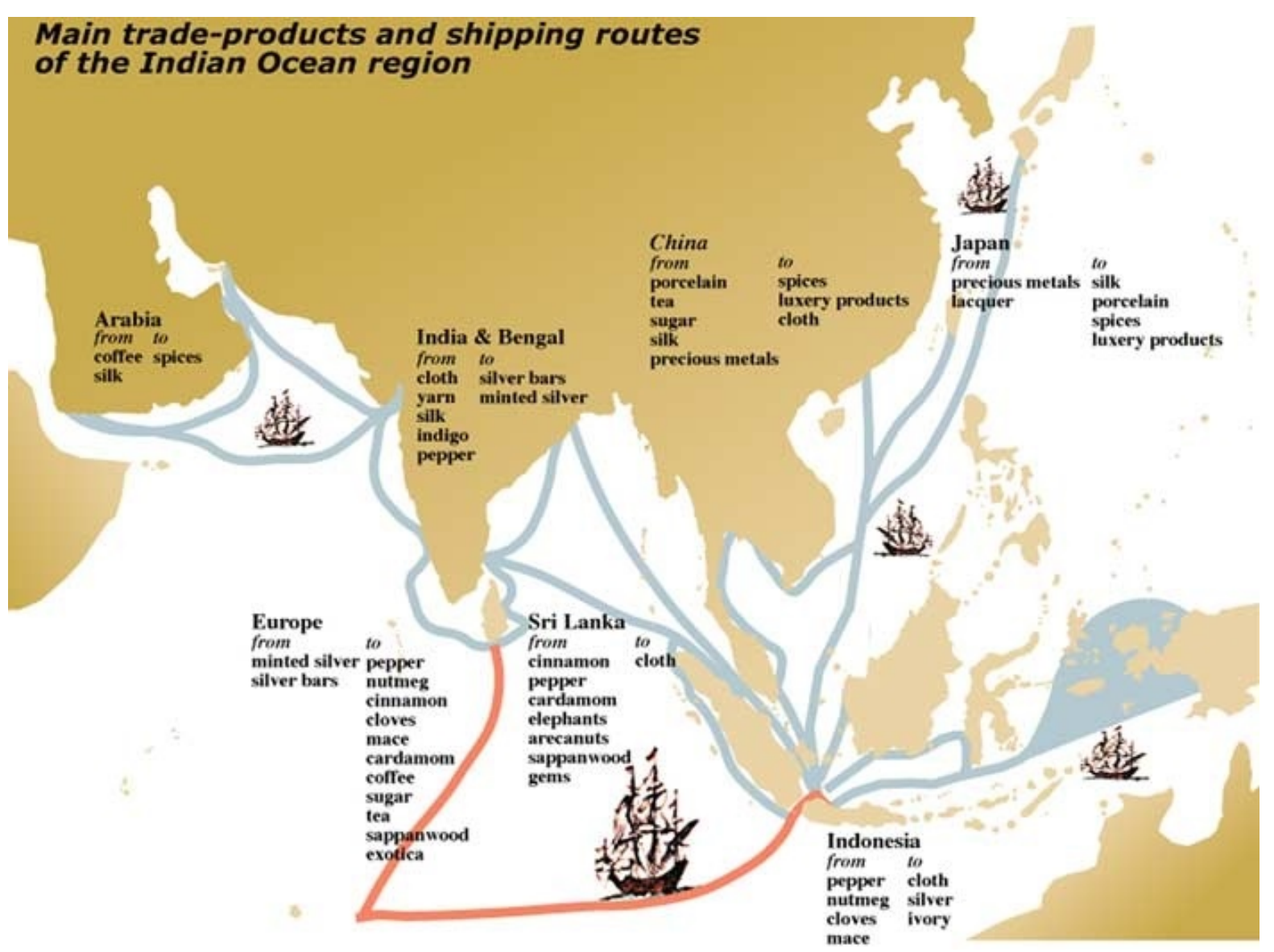

Figure 3. Dutch trade roots during the $16-17^{\text {th }}$ centuries

Source: http://maritimeasia.ws/maritimelanka/galle/voc_shipping.html

As the UP grew stronger, they were able to institute the first ever systematic blockage. By the end of the $16^{\text {th }}$ century and the beginning of the $17^{\text {th }}$ century, vessel design had improved sufficiently to permit Dutch warships to conduct a "blockade-like" operation against Spanish ports in Flanders, especially Antwerp. In 1630, in a major proclamation introducing a legal novelty in international relations, the Dutch extended "to the investment by sea of coast towns the principles applicable to a siege in land warfare", thus claiming a right to confiscate all neutral commerce (Davis \& Engerman, 2006, p. 416).

The Dutch-Portuguese conflict was costly for both sides and most of the capital of the Dutch West India Company was lost in the Brazilian war, which explains in part why the WIC was less durable and successful than the VOC. On the other hand, the war was even more costly for Portugal which, although it did regain Brazil, lost most of its Asian colonies and even more important, the lucrative spice trade. Portugal was definitely in decline by the $17^{\text {th }}$ century.

\section{The Rise of a Commercial Economy}

The external shock and the turn to the sea strategy through privateering as well as the emergence of the Dutch joint stock companies created a series of favourable circumstances 
for commercial and financial innovations such as the utilization of more specialized banking services and the introduction of the Dutch stock market in 1602.

Related to this, was the creation of the Bank of Exchange of Amsterdam of 1609, modelled on the Venetian bank of the Piazza di Rialto, which soon surpassed its Italian model. Merchants opened accounts in this Bank, then made money transfers from one account to the other without requiring actual money payments. This was another innovative institutional mechanism that promoted the interests of merchants and the economy as a whole. This banking practice was adopted subsequently by many other countries (van Dillen, 1934; Van Nieuwkerk, 2009).

At this point, the work of Gelderblom and Jonker (2004), who have analysed the evolution of the Amsterdam capital market as a consequence of Dutch overseas expansion and the introduction of transferable VOC shares, is very informative. It is obvious that the formation of the Dutch stock market led to the lowering of transaction costs concerning commercial activity. Also, in accordance to this, journals that quoted the prices of stocks appeared around 1606 (Kyriazis \& Metaxas, 2011, p. 366). This was an important major innovation not known among other stock exchanges of the time, as a transaction cost reducing mechanism.

Another aspect of the functioning of banks and the stock market was the necessity to create an efficient environment of property rights protection. A series of social groups that were contributing to the rise of the Dutch economy, such as merchants, ship owners, businessmen and bankers had more than one reason to securitize their property rights and this trend expanded to the whole of society. The proper functioning of banks, joint stock companies and the stock market provided the existence of an efficient institutional framework that securitized commercial transactions, securitized the legal binding of contracts and recognized property rights and ownership.

The protection of property rights is still regarded as a key prerequisite for economic development. There is a vast literature that verifies this (Demsetz, 1967; Alchian \& Demsetz, 1973; North \& Thomas, 1973; North \& Weingast, 1989; North, 1978, 1981, 1990, 2005; Williamson, 1975, 1991; Greif, 2005; Besley \& Chatak, 2010; Menard, 2014).

This protection of property gave an extra boost to the rise of the Dutch economy. We offer at this point an example of how an inefficient environment of property rights protection can lead to the decline of an economy, the case of Mughal India. During the 16th to 17th centuries Mughal India was a vast country, with vast plains, rivers and mountain in the northern parts and jungles in the south. The capital of the country alternated between Agra and Delhi according to the wishes of each emperor. The country was organized as a series of great geographical regions where a local governor ruled. However, in order to avoid any rebellion against them, the emperors frequently replaced the governors to avoid their becoming too powerful and acquiring a local power base. Furthermore, the property of the governors returned to the emperor at their death. Thus, local governors, without having the right of personal property did not have a stimulus to work efficiently. The Mughal India regime favoured short-run consumption and waste of money, rather than long term savings through property rights and investment. 
Thus local governors made exorbitant expenses in the short-run, unnecessary for the people and the economy, such as maintaining luxurious villas, as miniatures of the Emperor's wealth, having also very expensive and luxurious clothes and jewellery, having beautiful gardens, horses etc. All this dis-investment and waste of money lead to the gradual decline of the mighty Mughal India.

By contrast, in the UP during the same era, as we have shown up to this point, the basic foundations for the functioning of a modern economy had already been established. Thus a tiny European state, the UP, gradually became a global economic giant and geopolitical player whereas India, a great empire during the $16^{\text {th }}-17^{\text {th }}$ centuries declined and finally was converted into a colony of the British Empire. ${ }^{11}$

The Dutch success was based on economic freedom. The UP had a political system which favoured the undertaking of economic and commercial action by individuals. Merchants managed to place themselves in key positions on both local and national politics in the UP. They also offered employment to a great number of people since many Dutch found jobs as sailors in the merchant's ships or as employees in joint-stock companies.

The turn to the sea had also another positive result. It gradually converted the UP into a maritime state. Thus, a primitive version of what we could characterize in modern terms as secondary and tertiary sectors arose. Merchant ships, in order to undertake risky international voyages in the open oceans needed craftsmanship and a unique knowledge of maritime art. The secondary sector was under way: Huge shipyards were built. Companies which had developed technical expertise in producing mast, smelters, wood as well as bronze and the iron guns and power to equip the ships were introduced etc. Furthermore, in company with the maritime industry other parallel industries supporting maritime commerce arose, such as the dye industry, special kinds of food intended to last for long periods, such as smoked and salted food, biscuits, nuts and crackers and special kinds of cheese, etc.

Thus, the Dutch grand strategy of turning to the sea was combined with the rise of the secondary (shipbuilding etc.) and tertiary sectors (joint-stock companies such as the VOC, banking, the stock market, etc.).

But a notable number of Dutchmen were also serving (and thus finding employment) in the state galleons which were used as part of the new Dutch strategy: At first, to guarantee the safety of the regime and then, to assist and guarantee the rise of the UP as a global maritime empire. The UP managed to mobilize more resources for their defence compared to the centralized economies of states such as France which were ruled by an absolute monarch. The UP, with a population of no more than 2 million people, managed to mobilise armies and navies of about $5-6 \%$ of the population. This is the reason why the UP managed to stand up in

\footnotetext{
11 The English had followed the paradigm of the Dutch. After the repulse of the Spanish Armada, they turned to the sea as well. They established joint-stock companies, an efficient banking system and guaranteed the protection of property rights (Ormrod, 2003). The English East Indian Company, which was similar to the VOC, expanded and colonized large geographical areas of India. Then India was converted into a colony of the British Empire after the so called "Indian Mutiny of 1857". For the EIC see, among others, Lawson (1993), Sutton (2010), Robins (2012) and Roy (2012).
} 
the wars against France during 1672-1676 and England during 1672-1674 although both states were much more superior in human resources (France had a population of about 18-20 mio and England approximately 8 mio).

During the $17^{\text {th }}$ century, the UP were engaged in three wars with England, during 1652-1654, 1665-1667 and 1672-1674. In 1666 the Dutch fleet, under the leadership of Admiral Michiel de Ruyter, won a decisive victory over the English which determined the final outcome of the war in favour of the Dutch.

Table 2 offers a series of available statistical data based on the seminal book of Jan Glete's (1993) Navies and Nations, while in Diagram 1, which is based on the data of Table 2. Diagram 1 shows a gradual rise in the number of newly launched ships since 1615 . However, this rise is steadily reduced after 1631 . Table 3 , which is linked to Table 2 , shows the construction of new sailing warships for the period 1650-1680 (displacement in 1000 tons). It shows the strength of the Dutch navy in numbers, which is comparable only to those of England and France. This data verifies that the UP navy was a formidable force which guaranteed UP's grand strategy as a commercial empire globally. Despite being involved with ongoing warfare engagements, the UP became the richest country of the world till the 1750's, when England, now as a part of The United Kingdom, had risen and gradually took over the scepter of global hegemony.

Table 2. The strength of the Dutch navy 1615-1650 trend

\begin{tabular}{llll}
\hline Year & Number of warships & Year & Number of warships \\
\hline $1615 / 16$ & 50 & 1631 & 125 \\
1621 & 56 & 1642 & 120 \\
1628 & 110 & 1650 & 62 \\
\hline
\end{tabular}

Source: (Glete 1993, p. 156).

Table 3. Construction of new sailing warships 1650-1680 (displacement in 1000 tons)

\begin{tabular}{lllllll}
\hline Year & England & Netherlands & France & Denmark \& Norway & Sweden & Portugal \\
\hline $1651-55$ & 38 & 50 & 2 & 1 & 6 & 13 \\
$1656-60$ & 9 & 13 & 6 & 2 & 3 & 16 \\
$1661-65$ & 5 & 46 & 20 & 10 & 9 & 19 \\
$1666-70$ & 27 & 41 & 83 & 7 & 7 & 17 \\
$1671-75$ & 18 & 11 & 47 & 6 & 6 & 12 \\
$1676-80$ & 42 & 8 & 30 & 4 & 6 & 18 \\
\hline
\end{tabular}

Source: Glete (1993, p. 199). 


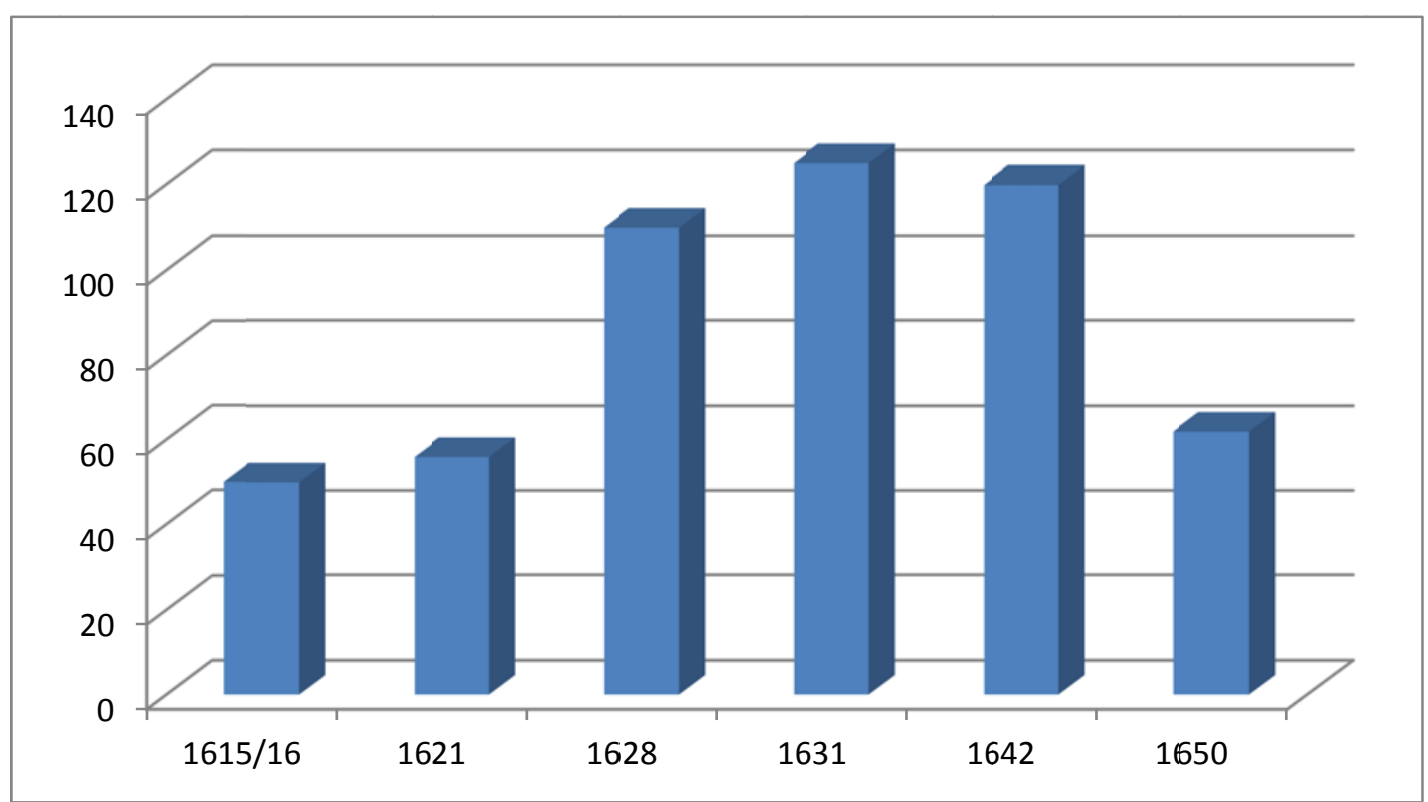

Diagram 1. The strength of the Dutch navy's trend during 1615-1650 (sailing warships)

Source: (Glete, 1993, p. 156)

\section{Conclusions}

We have traced the development in parallel, of the emergence of a new political and economic culture in the United Provinces after the revolt against Spain.

Because the UP did not have a strong central authority, they had to develop new institutions, both political and economic, to fill the gap. In the economy, they were market oriented, among others, having established joint-stock companies. Joint stock companies were adapted also to wage a "war for profit" by Dutch privateers, which proved to be successful.

Although not a democracy, the UP had democratic elements, protected property rights and were the most open and tolerant society of its period. They functioned as a federation (together with the Swiss, the oldest federation in modern history) with a fine balance of powers between the various levels, federal, provinces and states.

The most important lesson in the long run from the UP was that it was based upon the perception of a community of interests by the various groups living in the UP, aristocrats, merchants, bankers and entrepreneurs (the rejenten class), citizen- burghers, sailors and farmers. On the whole, they perceived that the UP's turn to the sea profited all of them, even though to different degrees. Thus, the political system was durable for more than two centuries and the economy was growing.

If we consider the European Union to be striving towards the goal of becoming a true federation then, some lessons can be drawn from the example of the UP as well as from the 
ancient Greek federations. ${ }^{12}$ The most important is that durable federations are based on the perception of a community of interest, and this seems to be missing in today's EU. At the time of its introduction, with the results of World War II still vivid, Europeans perceived as their community of interests the aim of avoiding another European war. The establishment of the then Common Market seemed to be the best way of achieving this.

Almost 60 years later, this is taken for granted, but a new sense of community of interest seems to be lacking. The EU, with its complex institutional setting, its distant bureaucracy and the lack of a common enemy (as was the case with the UP, which was always threatened by enemies (Spain, France, England) has not found a new "catchword" to inspire its peoples. Further, it shows a democratic deficit, in some instances a lack of solidarity, as for example, in sharing the burden of illegal immigration.

As to the democratic deficit, the EU has only one body that is elected directly by European citizens, the European Parliament, which still has restricted competences, although they have been strengthened during the last years.

So, we would propose that more democratic procedures should be introduced at the EU level. This could take two steps: First, the leading positions of the EU institutions, the President, the President of the Commission and the "Foreign Affairs Minister", should be elected by the European citizens. Second, popular initiatives on issues of European interests should lead to obligatory referendums with binding outcomes, as is the case in other federations, (e.g, Switzerland, Uruguay, New Zealand) and states within federations (as in the USA and Germany). ${ }^{13}$

These measures would at least reduce the democratic deficit and increase somewhat the feeling of European citizens that they share at least a democratic community of interests.

\section{Acknowledgements}

The authors wish to thank Nicholas Rodger and Henning Hillmann for their valuable comments and suggestions.

\section{References}

Alchian, A. A. Demsetz, H. (1973). The Property Right Paradigm. The Journal of Economic History. 33(1),16-27. http://dx.doi.org/10.1017/S0022050700076403

Besley, T. Chatak, M. (2010). Property rights and economic development. In D. Rodrik \& M. Rosenzeweig (Eds.), Handbook of Development Economics (pp. 4525-4595). Oxford and Amsterdam: North Holland. http://dx.doi.org/10.1016/B978-0-444-52944-2.00006-9

Boxer, C. R. (1965). The Dutch seaborne empire, 1600-1800. Hutchinson.

Cooper, J. P. 1970. The decline of Spain and the Thirty Years War 1609-48/49. In The New Cambridge Modern History, IV, (pp. 226-238). Cambridge: Cambridge University Press.

\footnotetext{
${ }^{12}$ For the political and economic organisation of the ancient Greek federations see, among others, Mackil (2013) and Economou, Kyriazis and Metaxas (2014).

${ }^{13}$ The Treaty of Lisbon provides for initiatives whose outcome is not binding. None has been undertaken yet.
} 
http://dx.doi.org/10.1017/CHOL9780521076180.008

Davids, K. t' Hart, M. (2012). The navy and the rise of the state: The case of the Netherlands c. 1570-1810. In J. Backhaus, N. Kyriazis \& N. Rodger (Eds) Navies and state formation (pp. 273-316). Berlin: Lang Verlag.

Davis, L. E. Engerman, S. L. (2006). Naval blockades in peace and war. An economic history since 1750 . Cambridge: Cambridge University Press. http://dx.doi.org/10.1017/CBO9780511511974

Demsetz, H. (1967). Toward a Theory of Property Rights. The American Economic Review. $57(2)$, 347-359. http://www.econ.ucsb.edu/ tedb/Courses/Ec100C/Readings/Demsetz_Property_Rights.pdf

Den Heijer, H. (2002). The VOC and the exchange. Amsterdam: Euronext.

De Vries, J. Van der Woude, A. (1997). The first modern economy. Cambridge: Cambridge University Press. http://dx.doi.org/10.1017/CBO9780511666841

Economou, E. M. L. Kyriazis, N. \& Metaxas, T. (2014). The Institutional and Eeconomic Foundations of Regional Proto-federations. Economics of Governance. http://dx.doi.org/10.1007/s10101-014-0155-4

Erikson, E. (2014). Between monopoly and free trade: The English East India Company. Princeton: Princeton University Press. http://dx.doi.org/10.1515/9781400850334

Ferguson, N. (2009). The ascent of money. A financial history of the world. New York: Penguin Books.

Furubotn, E. G. \& Pejovich, S. (1972). Property Rights and Economic Theory: a Survey of Recent Literature. Journal of Economic Literature. 10(4), 1137-1162. http://citeseerx.ist.psu.edu/viewdoc/download;jsessionid=94F1C9AF2C901CFC08587A3EB EF627A2?doi=10.1.1.471.2651\&rep=rep1\&type $=$ pdf

Gaastra, F. S. (2003). The Dutch East India Company. Zutphen: Walburg Press.

Gelderblom, O. Jonker, J. (2004). Completing a Financial Revolution: The Finance of the Dutch East India trade and the Rise of the Amsterdam Capital Market, 1595-1612. The Journal of Economic History, 64, 641-672. http://dx.doi.org/10.1017/S002205070400292X

Glete, J. (1993). Navies and nations. Warships, navies and state building in Europe and America 1500-1860. Stockholm: Akademitryck AB:

Goldsmith, R W. (1983). The financial development in India, 1860-1977. New Heaven and London: Yale University Press.

Greif, A. (2005). Commitment, coercion, and markets: The nature and dynamics of institutions supporting exchange. In C. Ménard \& M. Shirley (Eds.) Handbook of New Institutional Economics (pp. 727-786). Dordrecht, Berlin and New York: Springer. http://dx.doi.org/10.1007/0-387-25092-1_29 
Halkos, G. Kyriazis, N. (2005). Naval Revolution and Institutional Change: The Case of the United Provinces. European Journal of Law and Economics 19(1), 41-68. http://dx.doi.org/10.1007/s10657-005-5275-4

t' Hart, M. (1996). The making of a bourgeois state: War, politics and finance during the Dutch revolt. Manchester: Manchester University Press.

Hildreth, R. (1837, repr. 1971). The history of banks to which is added: A demonstration of the advantages and necessity of free competition in the business of banking. New York: Sentry Press.

Israel, J. I. (1995). The Dutch republic: Its rise, Greatness and fall, 1477-1806. Oxford: Clarendon Press.

Konstam, A. (2001a). The Armada Campaign. Osprey Campaign 86.

Kyriazis, N. (2006). Seapower and Socio-economic Change. Theory and Society 35(1): 71-108. http://dx.doi.org/10.1007/s11186-006-6788-8

Kyriazis, N. Zouboulakis, M. (2004). Democracy, Sea power and Institutional Change: An economic analysis of the Athenian naval law. European Journal of Law and Economics 17,117-132. http://dx.doi.org/10.1023/A:1026342010780

Kyriazis, N. Metaxas, T. (2011). Path Dependence and Change and the Emergence of the First Joint-Stock Companies. Business History 53(3), 363-374. http://dx.doi.org/10.1080/00076791.2011.565513

Kyriazis, N. (2012). Spices and the road to capitalism. In J. G. Backhaus (Ed.) Navies and states: The Schumpeter hypothesis revisited and reflected (pp. 365-380). Berlin: Lit Werlag.

Lawson, P. (1993). The East India Company: A history. London: Longman.

van Loo, I. (1998). For freedom and fortune: The rise of Dutch privateering in the first half of the Dutch revolt, 1568-1609. In M. van der Hoeven (Eds) Exercise of arms. Warfare in the Netherlands 1568-1648, (pp. 173-196). Leyden: Leyden-Brill.

MacKil, E. (2013). Creating a common polity: Religion, economy, and politics in the making of the Greek koinon. Berkeley and Los Angeles: University of California Press. http://dx.doi.org/10.1525/california/9780520272507.001.0001

Ménard, C. (2014). The contribution of Douglass C. North to New Institutional Economics. In Institutions, property rights and economic growth: The legacy of Douglass North. (pp. 11-29). Cambridge: Cambridge University Press. http://dx.doi.org/10.1017/CBO9781107300361.003

North, D. Thomas, R. P. (1973). The rise of the western world: A new economic history. Cambridge: Cambridge University Press. http://dx.doi.org/10.1017/CBO9780511819438

North, D. (1978). Structure and Performance: The Task of Economic History. Journal of Economic Literature. 16(3), 963-978. 
North, D. (1981). Structure and change in economic history. New York: W.W. Norton \& Co.

North, D. Weingast, B. (1989). Constitutions and commitment: The evolution of institutional governing public choice in seventeenth-century England. The Journal of Economic History. 49(4), 803-832. http://dx.doi.org/10.1017/S0022050700009451

North, D. (1990). Institutions, institutional change and economic performance. Cambridge: Cambridge University Press. http://dx.doi.org/10.1017/CBO9780511808678

North, D. (2005). Institutions and the performance of economies over time. In C. Menard \& M. Shirley (Eds.). Handbook of New Institutional Economics (pp. 21-30). Berlin: Springer-Verlang. http://dx.doi.org/10.1007/0-387-25092-1_2

Ormrod, D. (2003). The rise of commercial empires: England and the Netherlands in the age of mercantilism, 1650-1770. Cambridge: Cambridge University Press.

Parker, G. (1977). The Dutch revolt. London: Penguin.

Robins, N. (2012). The corporation that changed the world. London: Pluto Press.

Rodger, N. A. M. (1997). The safeguard of the sea. New York City: Harper Collins.

Rodger, N. A. M. (2004). The command of the ocean. London: Penguin-Allen-Lane.

Roy, T. (2012). The East India Company. The world's most powerful cooperation. New Delhi: Allen Lane-Penguin Books India.

Schmitthoff, C. M. (1939). The Origin of the Joint-Stock Company. The University of Toronto Law Journal. 3(1), 74-96. http://dx.doi.org/10.2307/824598

Steensgaard, N. (1982). The Dutch East India Company as an institutional innovation. In M. Aymard (Ed.), Dutch capitalism and world capitalism (pp. 235-257). Cambridge: Cambridge University Press.

Tincey, J. (1988). The Armada Campaign. Osprey Elite 15.

Toynbee, J. A. (1946, repr. 1966). A study of history. Oxford: Oxford University Press and Dell Publishing Co.

Van Dillen, J. C. (1934). History of the public banks. The Hague: Nijhoff.

Van Nieuwkerk, M. (2009). The bank of Amsterdam. On the origins of central banking. Amsterdam: Sonsbeek Publishers.

Williamson, O. (1975). Markets and hierarchies: Analysis and antitrust implications. Free Press: New York.

Williamson, O. (1991). Comparative Economic Organization: The analysis of Discrete Structural Alternatives. Administrative Science Quarterly, 36, 269-296. http://dx.doi.org/10.2307/2393356

Zandvliet, K. (2002). Mapping for money. Maps, plans and topographic paintings and their 


\section{Macrothink}

International Journal of Social Science Research

ISSN 2327-5510

2015, Vol. 3, No. 2

role in Dutch overseas expansion during the 16th and 17th centuries. Amsterdam: Batavia Lion International.

\section{Copyright Disclaimer}

Copyright for this article is retained by the author(s), with first publication rights granted to the journal.

This is an open-access article distributed under the terms and conditions of the Creative Commons Attribution license (http://creativecommons.org/licenses/by/3.0/). 